\title{
A PERSONAL LOOK AT THREE SWEDISH POETS: CARL MICHAEL BELLMAN, ESAIAS TEGNÉR, ERIK JOHAN STAGNELIUS ${ }^{1}$
}

\author{
PIOTR KLAFKOWSKI \\ University of Szczecin \\ Institute of Sociology \\ Ethnology and Cultural Anthropology Unit \\ Krakowska 71-79, 71-017 Szczecin, Poland \\ e-mail: pklafkowski@gmail.com \\ (nadesłano 28.08.2017; zaakceptowano 7.09.2017)
}

\begin{abstract}
The paper is the author's personal homage to his three favourite Swedish poets. It attempts at showing the Polish readers that Sweden, too, had its share of great poets, as Swedish poetry is almost wholly unknown in Poland. Carl Michael Bellman is compared with his contemporary Robert Burns, Esaias Tegner is presented in the context of epic poems of Denmark and Norway, whereas Erik Johan Stagnelius - in comparison with John Keats and William Blake.
\end{abstract}

\section{Key words}

Swedish poetry, Sweden in the late 18th century, Carl Michael Bellman, Esaias Tegner, Erik Johan Stagnelius.

\section{Abstrakt}

Artykuł stanowi osobisty hołd autora złożony jego trzem ulubionym szwedzkim poetom. Jest to również próba pokazania polskiemu odbiorcy, że Szwecja także miała

\footnotetext{
1 Special invited contribution.
} 
szereg wielkich poetów, chociaż są oni w Polsce prawie nieznani. Po krótkim wprowadzeniu historycznym omówieni zostają wymienieni w tytule twórcy. Carl Michael Bellman przedstawiony jest w porównaniu z jego szkockim równolatkiem Robertem Burnsem, Esaias Tegner - na tle duńskiej i norweskiej poezji epickiej, Erik Johan Stagnelius porównany jest z dwoma poetami angielskimi: Johnem Keatsem (niemal równolatkiem Stagneliusa) oraz Williamem Blakiem. Tekst zawiera kilka ilustracji, cytatów z wierszy Bellmana i Stagneliusa (cytaty z Tegnera byłyby zbyt długie, jako że mamy do czynienia z poezją epicką), obszerną bibliografię dzieł w językach szwedzkim, angielskim i polskim oraz znaną autorowi dyskografię pieśni Bellmana oraz muzyki powstałej do dzieła Tegnera.

\section{Słowa kluczowe}

Szwecja pod koniec XVIII wieku, Liga Gotycka, fosforyzm, Carl Michael Bellman, Esaias Tegner, Erik Johan Stagnelius.

Dedicated to:
- The memory of Mr. Claes Nyegaard (1920-1999) of Damms
Antikvariat ${ }^{2}$, Oslo, the Greatest Antiquarian and Gentleman
I have ever known, in whose Antikvariat I first met Esaias Tegnér;
- The memory of Bjørn Ringstrøm of Oslo (1928-2015), in whose
Antikvariat I first met Erik Johan Stagnelius;
- The children of Vettre School on Oslofjorfd in 1990-1992, who
never ever tired of singing Bellman's Old Man Noah to the under-
signed. I hope you still remember me.
Thank you for everything you taught me.

$P K$

\section{Introductory}

I would like to begin this paper by explaining why I have written it. When I returned to Poland after thirteen years in Norway I was immediately struck by how little was the Scandinavian culture known to the Polish general public. Denmark was universally associated only with Hans Christian Andersen and his fairy tales. Norway seemed to fare a little better: many people seemed to know at least the names of Edvard Grieg, Sigrid Undset, Henrik Ibsen, Knut Hamsun, and the cinema lovers remembered that the Polish movie Żywot Mateusza of 1967 (directed by Witold Leszczyński, starring

2 I prefer to use the Norwegian word „Antikvariat”, as its primary connotation is the place for old books, not Dickensian Old Curiosity Shop. I also think that there is a world of difference between "old books" and "second hand books". 
Franciszek Pieczka) was based on the Norwegian novel Fuglene of 1957 (Polish translation Ptaki 1964) by Tarjei Vesaas (1897-1970)3.

Sweden, or to be precise, Swedish literature, fared much worse. It seemed to me that the only names my respondents knew were Astrid Lindgren and Ingmar Bergman. The Swedish literature seemed to be totally unknown, and my quoting the Swedish Romantic poets was frequently met with genuine surprise of the type "you mean they had any?". The movie lovers remembered Sommaren med Monika of $1952^{4}$ and Hon dansade en sommar of $1951^{5}$, or at least the scandals caused by those movies ${ }^{6}$, and of course they could recite the titles of all the films by Bergman. However, Master Ingmar has successfully convinced the audiences that Sweden is a dark country, gloomy realm of lower middle-class hypocrites, completely deprived of joy, smiles, emotional subtlety and any romantic feelings. Bloody past, gloomy present sealed by the seventh seal $^{7}$, period ${ }^{8}$.

Nobody seemed to know that it was a Swede - Emmanuel Swedenborg (16881772) - who authored what is probably the most beautiful book on both the marital and the extramarital love: Delitiae Sapientiae de Amore Congugiali post quas sequuntur Voluntates Insaniae de Amore Scortatorio ab Emanuele Swedenborg, Suecio, $1768^{9}$.

I have even met some younger people who did not know that ABBA was a Swedish group "because they sang only in English, didn't they?".

But, after all, also in Scandinavia - I almost wrote "But, after all, even in Scandinavia" - we find great romantic poetry, full of subtle feelings, easily equalling the English, Russian, German, or Polish masters of words. All they need is being introduced in Poland in the right way.

A handy conference on Swedish culture ${ }^{10}$ provided an opportunity of presenting three of my most favourite Swedish poets to the Polish public. The paper was in Polish.

3 Though, to be precise, Ibsen wrote in Danish and was proud of it, and the language of Sigrid Undset's novels is definitely more Danish than Norwegian. Of the writers mentioned, only Tarjej Vesaas wrote in pure Norwegian.

4 Based on Per Anders Fogelstrm's (1917-1998) novel Sommaren med Monika of 1951 (Polish translation titled Wakacje z Monika by Aleksander Szulc 1960) starring Hariet Andersson and directed by the young Ingmar Bergman. The Polish title of the movie was the same as the title of the translation of the novel.

5 Based on the novel Sommardansen of 1949 by Per Olof Ekstrm (1926-1981), starring Ulla Jacobsson, directed by Arne Mattisson. The Polish title of the movie was Ona tańczyła jedno lato.

6 These two movies launched the myth of Sweden as a country of unrestrained physical love.

7 Yes, I do mean Bergman's famous Det sjunde inseglet of 1957.

8 I invite the skeptical reader to study Ronald Hundford's The New Totalitarians (London 1971) or Jacek Kubitzky's Szwecja od środka (1987) and Alfabet szwedzki (2011) to experience the land of Bergman in its fullness.

9 Swedenborg wrote only in Latin. This particular work of his has been translated into English many times. The best modern rendering that I have seen is titled The Sensible Joy in Married Love and the Foolish Pleasures of Illicit Love, translated by David H. Gladish, Swedenborg Foundation, West Chester (Pennsylvania) 1992.

10 This conference, titled International Anthropological Conference: Swedish Tradition, Customs and Esthetic Sensitivity on the Example of the Culture of Hälsingland Region, was organized by Chair of 
It now appears in English, which makes my task more difficult, as I have no access to the English translations of the poems (except a few), only to the Polish renderings and some originals. Anyway, I hope that my sketch will make some readers interested in looking for more.

The three poets I have chosen are the following:

Carl Michael Bellman 1740-1795

Esaias Tegnér 1782-1846

Erik Johan Stagnelius 1793-1823.

The choice is the undersigned's own heart - I simply like these three more than any other Swedish poets whose works I have read. Besides, their poems are available in Polish, and it was the Polish audience that I wanted to reach. I do not go into biographic details of them all, as my intention is to give an impression, an impulse for further study. The basic references are given in the bibliography. For the sake of clarity, I will also add that "Scandinavia" in this paper means only the three countries of Sweden, Norway and Denmark, excluding the Faroe Islands, Iceland, Kalallit Nunaat (formerly known as Greenland) and Sapmi (formerly known as Lapland).

As I have no access to the published English translations of Bellman and Stagnelius, I quote passages from their poems available on the web in the PoemHunter.com portal. These quotations are marked (PH). My own translations are marked (PK).

The subject of this paper being poetry and its personal appreciation, I allowed myself to be more personally involved than the current academic fashions allow. I hope my readers will not hold it against me.

\section{The Historical Background}

It is necessary to begin with a few words on Sweden at the end of the 18th century. It was the period of the origin and development of Swedish enlightened absolutism culminating with the assassination of king Gustav III in March $1792^{11}$. The beginning of the 19th century in Swedish history is the loss of Finland to Russia, the banishment of king Gustav Adolf IV, the reign of Karl XIII (known in Norway as Karl II), and finally the coming to power of the Frenchman Jean Battiste Bernadotte as the king Karl XIV Johan ${ }^{12}$. This is the period in which Sweden tries to regain its strength after being defeated by Peter the Great of Russia in the early 18th century. In 1814, on the basis of the Treaty of Kiel - the North-European equivalent of the Congress of Vienna (1814-1815) - Sweden takes over Norway from Denmark.

The three poets I have chosen, besides their literary achievements, are a very interesting group from the point of view of cultural anthropology and the anthropology of literature. Bellman came from a middle-class family. Tegnér, son of a peasant family,

Ethnology and Cultural Anthropology, University of Szczecin, on October $5^{\text {th }}, 2015$.

11 This event is the subject of one of Giuseppe Verdi's best-known operas, Un ballo in maschero/The Masked Ball, of 1859.

12 He was born in 1763, was one of Napoleon's best field commanders, rose to the ranks of the marshal of France in 1804, and became the king of Sweden and Norway in 1818. His best, most detailed biography is available only in Swedish, see Höjer 1939-1960. 
was educated at the famous (until this very day) university of Lund, where for many years he was a professor of Greek; he spent the last 20 years of his life as the bishop of Växsjö. Stagnelius came from a rather poor family connected with the Church of Sweden and for various reasons presents a wholly different picture from his two much better-known poetic predecessors.

\section{Carl Michael Bellman 4.02.1740 - 11.02.1795}

A close contemporary of Haydn (1731-1809), Mozart (1756-1791), and Robert Burns (1759-1796), Bellman defies easy labelling. He was born in a well-to-do upper middle-class family. His father was a civil servant working at the royal chancery. Bellman was educated mostly by private tutors. He tried making his living as a bank employee, did not like the job, spent one term as a student at Uppsala university, then again tried working at a bank, went personally bankrupt and had to flee to Norway to avoid arrest, became a famous poet and a bard of Stockholm's guttersnipes and tipplers, and eventually got a sinecure job from the Swedish king Gustav III which was intended to give him financial safety for the rest of his life. However, though not unexpectedly, Bellman, who already suffered of tuberculosis, landed in jail in 1794. It was in jail that he wrote a brief account of his life ${ }^{13}$.

Something rather unusual happened to him when he was a boy. He fell ill, had high fever, and when he recovered he discovered he could express himself in fluent poetry, the gift he apparently had not had before ${ }^{14}$.

Bellman is best known today as a poet and a composer. He wrote poetry all his life. It was probably at the time he tried being a student at Uppsala that he started drinking and composing drinking songs. His output includes numerous religious poems as well, but these are not as well-known as his two masterpieces, 82 Fredmans Epistler (Fredman's Epistles, 1790) and 65 Fredmans sånger (Fredman's Songs, 1791). These titles could be properly translated as Freeman's Epistles and Freeman's Freeman's Songs.

Similarly to Robert Burns, Bellman set his poems to music and sang them accompanying himself on the instrument today called cittern ${ }^{15}$, similar to a small and flat-

\footnotetext{
13 See Neuger 1991, pp. 244-248.

14 According to Bellman himself, it was when he lay with high fever he started talking and singing in rhymes to his mother (Neuger 1991, p. 246). This strange episode is mentioned in Bellman's biography available on the web, Wikipedia (English), access 10.07.2017. However, according to the Wikipedia, Bellman discovered the sudden poetic gift only when he recovered, a small but important difference.

15 The musical gift ran in the family - according to Neuger, Bellman's grandfather was famous for his improvisations on cittern (Neuger 1991, p. 242). According to Swedish sources, Bellman played the instrument his grandfather had bought when he was in Rome. Unfortunately, the luthier's name is not given.
} 
tened lute with six courses or pairs of strings ${ }^{16}$. He had the reputation of an unrivalled virtuoso of the instrument ${ }^{17}$.

Bellman came to fame as merciless scoffer ridiculing all the pompous eminences of his epoch in the way that was elegant and refined - and therefore even more murderous. Some compare him to the Mozart shown by Miloš Forman in the well-known movie Amadeus of 1984. Maybe there is a point to it. However, Bellman reminds me, first and most of all, of Ignacy Krasicki with his unforgettably vitriolic pen ${ }^{18}$, with the elegant but merciless ridiculing everything that deserves ridiculing.

The earlier collections of Bellman's poems - Månan (The Moon, 1760) and Bacchi Tempel (Temple of Bachus, 1783) today seem to be remembered only in Sweden.

The chief protagonist of Bellman's most famous works, Fredman's Songs, is a Free Man proud of his freedom, the man who always has his own opinion - generally critical - of the officially accepted greats and eminences of this world. The shining salons full of pompous "higher spheres" pursuing the ignoble art of self-admiration are as far from Fredman as one can imagine. Despising those gas bags, Fredman seeks company there where ridiculing the greats will be accepted with an open heart (and moneybag!) - at a pub, a tavern, a drinking den where no one pretends, where one can be himself. Probably no other Scandinavian poet has sung - literally! - so many hymns to drinking, to imbibing strong and still stronger booze than Bellman, or more properly, Fredman. However, these are NOT ramblings of a dipsomaniac, the but the proud posture of one who knows his choice and fully realizes what others may think about him. It is in this all-embracing pride, in the might of the individuality, in the charisma that outshines all ridicule, that Bellman comes closest to his great Scottish contemporary Robert Burns. What a pity the two have never met!

The very title Fredman's Epistles hints at a parody of New Testament Epistles, as the word "epistle" has a clear religious tinge in the Lutheran world. According to Neuger", Fredman's Epistles have originally been intended a parody of St. Paul's Epistles, and each of them had a clearly-stated sender and addressee. However, the Epistles developed into something else - a series of moral teachings given by Fredman using the examples taken from his favourite setting of watering holes and their regulars of both sexes. The explanatory titles remained. Let us have a look at some examples:

Epistle 23, being Fredman's soliloquy when he was lying flat (= in the gutter, PK) not far from the Crawl in Here pub across the Banking House on one summer night of 1768 (PK);

16 The cittern had many variants ranking from 4 to 7 courses and it is not easy to say what tuning was used by Bellman. However, his best-known portrait shows him playing a six-course instrument, which suggests CGDADG or CGDADA as the likely tunings that Bellman might use.

17 According to the entry „Cittern” In English-language Wikipedia, Bellman's instrument has survived and is now in the collections of the National Museum, Stockholm. However, the Museum's portal answers "Your search has produced no hit" (as of 16.08.2017).

18 Ignacy Krasicki lived 1735-1801. Some of his best-known collections of poems putting him beside Bellman are Mouseiad (1775), War of the Monks (1778), Fables and Parables (1779), Satires (1779), finally New Fables published posthumously (1802).

19 In his Polish translation of Bellman, p. 249. 
Epistle 41, marking the happenstance when Chrystian Wingmark ${ }^{20}$ lost his dressing-gown in a clash with Mollberg (PK);

Epistle 45, to Father Mollberg upon his harp, being also a kind of ad notitiam giving witness to the fact that Mollberg has suffered innocently in the Rostock pub (PK) ${ }^{21}$.

Fredman's Epistles remain a parody of Pauline Epistles, but on a rather refined level - the one of form and associations rather than direct ridicule. Fredman's Songs, in turn, achieve the same effect by making outright fun of numerous Biblical personalities chiefly of the Old Testament.

Fredman's Songs and Epistles popularity in Sweden and the entire Scandinavia cannot be compared with any other work by any other Nordic poet. They entered folklore and are known, and frequently sung, by people who do not know they are Bellman's, for the simple reason that "they have always been!". Truly, monumentum aere perenius.

Fredmans works are sung, played, and recorded until today, sometimes with piety that produces an additional humoristic effect, though definitely not intended. Bellman's music arranged for various chamber groups - featuring the violin, viola da gamba or cello, lute, guitar, harpsichord etc. - causes the songs to lose their greatest point which is simplicity (but it is Mozart's simplicity!) and their frankness, directness, straightforwardness. Seeing a concert singer, even an otherwise truly great one - of course attired in tailcoat, plastron white shirt and shining patent-leather black shoes trying, with full concentration on sheet-music on the music stand before him, to sing about the delights of a glass of beer or of pinching the ale-wife's bum, one does not know what to laugh at first - the Bellman humour or its unintended "serious music" parody with the operatic tenor or bass thundering about Bacchanalian delights.

While considering music it is worth noting that though Bellman was an exceptionally gifted composer - some sources say he was the greatest Swedish Rococo composer, thus placing him alongside with Mozart - he frequently used either folk tunes or the tunes of popular songs of the epoch; giving bacchanalian lyrics to popular, and probably serious tunes caused an additional effect. This brings to mind the scandal caused in Poland many years ago by Maciej Zembaty with his "sacrilegious" version of Chopin's Funeral March, or on a different emotional scale, Wojciech Młynarski’s arrangement of Boccherini's Minuetto.

We Poles are lucky - Leonard Neuger published a masterly translation of a selection of Fredman's Songs and Epistles in 1991. A detailed Afterword (pp. 229-263) and Explanatory Notes (pp. 264-274) introduce the reader to Bellman's Sweden and answer almost all the questions the reader might have on reading the poems. What a pity the book is not accompanied by a CD record - they were already in existence - which would give the reader the opportunity of meeting Fredman live. Also, I regret that the book features a highly modern, almost expressionist image of Bellman instead of

20 See Neuger 1991 p. 6 and p. 265 for the explanatory list of Fredman's Epistles heroes.

21 It is interesting that according to the poem, Father Mollberg was beaten up by some soldiers for publicly speaking up in defence of Poland, the incident which Neuger dates at the first partition of Poland in 1772 (Neuger 1991, p. 235). See Neuger 1991, pp. 235-237 for more about Poland in Bellman's Sweden. 
giving his contemporary portrait showing him playing his favourite cittern ${ }^{22}$. On the other hand, the dust cover design is pure Fredman! The translations are incredibly faithful and beautiful, only in very few places small changes might make the rhythm more fit for singing.

One of the most famous Fredman's Songs is No. 65, Old Man Noah, focusing on the weakness the captain of the Ark had for a glass of wine. Here is how it begins:

Old man Noah

Old man Noah

Was a funny guy.

As long as on board

He obeyed the Lord

But when Ark he disembarked

First thing he made was wine.

$(P K)$

After many a gulp Fredman concludes with praising good old days when there were no boring speeches at the table and nobody had to ask for permission, one just took a glass and drank.

It is worth noting that this particular tune has countless sets of lyrics known even to children, who love to sing it anytime.

Seen from Poland, Bellman reminds me most closely of Ignacy Krasicki and Stanisław Trembecki in the 18th century, and of Konstanty Ildefons Gałczyński and Julian Tuwim in our own times. In English (if English it is!) he is a close soul mate of Robert Burns, but sometimes his comparisons of warm pubs with cold churches, of proud poverty with shameless riches, bring William Blake to mind, for example in when reading Fredman's Song No. 24, The Alehouse:

A very tiny old church stood

At forest edge among the rocks.

For everyone it was a hub

Two windows' cleft

Door to the left

And it was called a pub.

$(P K)$

Compare Blake's Songs of Experience, The Little Vagabond, whose first words read:

Dear Mother, dear Mother, the Church is cold

But the Ale-house is healthy and pleasant and warm²3.

The two poems are close contemporaries, Bellman's poem is dated 1791, and Blake's - 1794.

Since the undersigned is an employee of the University of Szczecin, a Szczecin trace in Fredman's Epistle 1, to Cajsa Stina cannot be left unmentioned. Cajsa Stina is a diminutive form of Katarina Kristina. According to Neuger (p. 265), she may have

\footnotetext{
22 I am thinking about Per Krafft the Elder's (1724-1793) portrait of Bellman dated 1779 that accompanies Bellman's biography in the English-language Wikipedia (Access 1.10.2015).

23 See Blake's Songs of Experience, Blake 1977, p. 127.
} 
been a relative of the proprietors of Terra Nova pub at Skeppsbron (=Ships Wharf), and sometimes helped them at the tiddlywink. This pub was bought in 1720 by one Joachim Schachou of Szczecin. Neuger supposes that the man could be a Germanized Slav, maybe a Pole, whose original name was Szachoł.

I invite the readers to consult the internet portal PoemHunters.com for enjoying a small selection of Fredman's Epistles and Songs in excellent English translations. A selection of Fredman's works set to music is also available on YouTube at the address Carl Michael Bellman (access 10.07.17).

\section{Esaias Tegnér 13.11.1782 - 2.11.1846}

Esaias Tegnér was born in a poor family of a Lutheran pastor. The family was of peasant origin in both paternal and maternal lines. The father's original name was $\mathrm{Lu}-$ casson, but he changed it to Tegnérus after the name of the village he was born in, Tegnaby. It was his youngest son, the famous poet, who shortened the name to Tegnér ${ }^{24}$.

The young Esaias proved so excellent a pupil at school that in 1792, when his father died, he became an assistant and a scribe to the regional registrar. The registrar, seeing the exceptional inborn gifts of the boy, allowed him to join his own sons to receive private tuition. Tegnér became a student of Lund university in 1799, graduated with a degree in philosophy in 1802, became a tutor in Greek, and since 1812 he was a professor of Greek, the job he held until he became a bishop of Växjö in 182425. Since 1819 he has also been a member of the Swedish Academy. He held the bishop's dignity until his death in 1846 . His life is an example of how the unlimited thirst for knowledge can help one to rise from a peasant's son to a professor at a famous university.

For most of his life Tegnér struggled with attacks of melancholy and depression, which eventually developed into a mental disease that took his life.

His poetic debut of 1808 was a patriotic war song followed by Svea, a long patriotic poem, in 1811. It was Svea that was awarded the Swedish Academy Prize and made its author famous. As regards his artistic convictions, Tegnér was an enthusiastic member of the Gothic ${ }^{26}$ League $^{27}$. His writing slowly developed from short occasional poems. $\mathrm{He}$ was increasingly fascinated by the old Icelandic sagas, which are regarded the cor-

24 In the Polish edition of Tegnér's Frithjof Saga Stanisław Wałęga suggests that the father or his family may have had some drawing abilities, as the word "tegner" means "drawer, he who draws". However, the Wikipedia biographies of the poet in Swedish and English do not say anything about it. 25 It was the king Karl XIV Johan that made Tegnér the Bishop. The biographies of the poet stress In various ways that although Tegnér was not strongly connected with the Lutheran Church of Sweden, making him a bishop was the royal recognition of his greatness as a poet. One feels tempted to conclude that at east one king recognized a great poet by giving him a high rank rather than jailing him. 26 "Gothic" in the name does not refer to the Goths of Alaric, but to the Swedish island of Gotland, Sweden's largest island and the place full of old Swedish traditions.

27 Called Gotiska förbundet in Swedish, it was a literary club whose members were chiefly university people interested in the Nordic past and mythology. The club opened in 1811 and closed in 1844. It counted many great Swedish scholars and men of letters as its members or supporters. The Gothic League could well be called the cradle of Swedish Romanticism. 
nerstone of all Scandinavian literatures. Of particular interest to Tegnér was the Saga of Frithjof the Brave, usually dated for ca. 1300 CE. In 1820, he began writing his own poem based on the Saga. The first parts of it came out in Iduna, the Gothic League's journal, in 1820 and 1821. The complete poem was published in Stockholm in 1825 and brought the poet everlasting fame. It was one of the greatest literary sensations in Sweden and until today it remains the only major Swedish poem that is known - or at least should be known - to poetry readers all over the world. It has been translated many times into all the major European languages. The renderings quoted most frequently are two different German translations already in $1826^{28}$ (followed by many more) and the Russian translation of 1841 followed by the new one of 1935 . Some bibliographies seem to confuse the original Icelandic Saga and Tegnér's poetic retelling of it.

One of the main features of Tegnér's poem was the meter. The poem consists of 24 Cantos, each of which is written in a different meter, rhyming or not, showing the poetic richness of the Swedish language. The First and the Last Cantos are in hexameter, the traditional meter of epic poetry.

It is interesting to have a closer look at the history of the Polish translations of Tegnér's masterpiece. The chronology follows, based on Wałęga 1957:

- 1852 - a partial translation by Roman Zmorski (1842-1867). The translation was from German, not from the Swedish original, and featured many changes and misunderstandings by the translator.

- 1856 - the complete translation by Ludwik Jagielski (1821-1884), who was also a known painter. His translation is also from German.

- 1859 - the complete translation by Józef Grajnert (1831-1910), also from German. According to Wałęga Grajnert's translation, even though full of various mistakes and changes, distinguishes itself from the two previous ones by its "warmth and feeling".

- 1861 - the complete translation by Jan Nepomucen Wiernikowski (1800?-1877), according to Wałęa full of the same mistakes as the previous ones. The language from which Wiernikowski translated the poem is not specified, but the general context suggests German.

- 1957 - the complete translation by Stanisław Wałęga, the first translation of Tegnér's poem directly from the Swedish original with a long and detailed introduction.

In this age of the domination of English it is worth noting that it was Henry Wadsworth Longfellow (1807-1882) who translated some episodes from Tegnér's poems into English in $1837^{29}$. Longfellow travelled across Europe several times, getting acquainted with poetry new and old, and learning languages; it is worth noting he had at least the basic knowledge of Finnish and Swedish. His work, completed by others, is the best-known English rendering of Tegnér's masterpiece.

28 One of the earliest German enthusiasts of Tegnér's epic was Goethe himself (1749-1832).

29 See Robert L. Gale, A Henry Wadsworth Longfellow Companion, pp. 90-91 and 261, Greenwood Press, Westport (Connecticut) and London 2003, the work being in fact a Longfellow encyclopedia. 
During the 19th century many Swedish, German, Dutch and French composers set the whole poem or some of its parts to music. It has also become a source of many popular and folk songs of Sweden. Among those who wrote music based on Tegnér's poems we can mention the Germans - Max Bruch (1838-1920), Felix Draeseke (1835-1913), Heinrich Hofmann (1842-1902); the Dutch - Johan Wegenaar (1862-1941) and Cornelis Dopper (1870-1939); the Frenchman Théodore Dubois (1837-1924); and the Swedish composer Elfrida Andrée (1841-1929). It seems that only Max Bruch is still remembered, but thanks to his Violin Concerto No. 1 in G Minor, Opus 26, of 1867, not his Frithjof Cantata, Opus 23, of 1864.

An interesting witness to the popularity of Tegnér's poem in Germany is the monument to Frithjof presented by the German Kaiser Wilhelm II to the village of Vangsnes near the township of Balestrand, Vik district, Sogn og Fjordane County, Norway. It was unveiled in July 1913 and is still overlooking the Sognefjord. Some of my friends from that area used to say they never really got used to this monument, which in their opinion is more German than Scandinavian ${ }^{30}$.

In 1986, a group of eight young Swedish musicians recorded an LP titled Frithiofs Saga that was released by the Cinnober label. This extremely interesting record presents a selection of 16 Swedish songs based on passages from the various Cantos of Tegnér's poem and recovered, as the accompanying booklet says, from old school songbooks and sheet music. As far as I know, this collection has never been released as a $\mathrm{CD}$ record.

The readers of this paper are asked to excuse me for not quoting any passages from Tegnér's masterpiece. To give it full justice, I would have to quote a passage from each of its 24 Cantos, as each one is in a different meter. I can do no better than to refer the reader to the internet portal PoemHunter.com which features a small selection of Tegnér's poems in English, including three well-known fragments of the Frithjof Saga ${ }^{31}$.

Tegnér gave his country a true epos, something that Denmark does not have until now $^{32}$, and which Norway got only in the second half of the 20th century ${ }^{33}$. As a master of form, he might - just might - be compared with Juliusz Słowacki, Frithjof's Saga being a counterpart, albeit a remote one, of Słowackis Lilla Weneda. However, I do not think Tegnér can really be compared to any Polish Romantic poet, he is a phenomenon all unto himself.

\footnotetext{
30 A picture showing this monument can be seen on the web, the page titled Friđfjófs Saga Hins Frokna (accessed 5.07.2017).

31 PoemHunter.com (accessed 15.07.17).

32 Frederik Paludan Muller's (1809-1876) three-volume poem Adam Homo (1842-1849) is more a satirical and moral tale than an epic, though it has passages of highest grandeur. Adam Oehlenschläger's (1779-1850) poem Nordens Guder of 1818, though extremely interesting, cannot be called a Danish national epic. It seems that both Denmark and England are now competing for the famous poem Beowulf attributed to the $8^{\text {th }}$ century.

33 Hans Henrik Holm's (1892-1980) poems Jonsoknatt (St. John's Night, 1933) and the eight-volume Norsk Folke Epos (Norwegian Folk Epic, 1965-1972, see Klafkowski 1995 and 2016).
} 


\section{Erik Johan Stagnelius 14.10.1793-3.04.1823}

The third poet I wish to present is, in many ways, the most enigmatic one. We know very little about him. He was two years old when Bellman died, was Tegnér's junior by 11 years, yet he died 23 years earlier than the author of Frithjof's Saga. We know the future poet was born on the island of Öland ${ }^{34}$ and lived there until he was 16 years old. He had three brothers and two sisters. Both of his parents were connected with the Lutheran Church of Sweden: his father was a priest on the island and a titular professor of Greek, and his mother came from a priestly family. Already as a child he showed poetic talent. He studied at Uppsala, graduated in 1814, moved to Stockholm and spent the rest of his life as a clerk in a church chancery ${ }^{35}$. He knew several men who would later form the Gothic League, but did not seem to be attracted to their ideas. He lived alone in a small, dirty and cheap room, having no friends to visit him. His biographers stress that he seems to have had no emotional connections with any woman ${ }^{36}$. Those who knew him personally always stressed that he was extremely ugly and unattractive. What could it mean? It is known that he suffered from some disease that caused him intense pains throughout his life, and that he sought help in opium to relieve his suffering ${ }^{37}$. It is not certain what was wrong with him, and the only drawing of him that we know does not show ugliness, maybe only a somewhat disproportionate head. Some scholars suggest Stagnelius suffered from the so-called Noonan syndrome ${ }^{38}$. It is known that he was a heavy drinker and client of prostitutes, but he kept to himself and had very few closer acquaintances. His biographies say that about a month before his death he was stopped by police in the streets of Stockholm, for he was so terribly drunk that he was posing danger to himself and others. It is said that when he died, nobody came to his funeral, and that the inspection of his room resulted in finding a sack stuffed with manuscripts and rags, apparently to be thrown as garbage. It may reflect

34 The second largest Swedish island and the birthplace of several eminent Swedish poets and novelists.

35 In Swedish, the office he was employed is called "ecklesiastikexpeditionens kansli", that might be approximated in English as "ecclesiastic correspondence chancery". Though the lexicon is similar, the names of various Swedish institutions do not easily translate into English.

36 Many of his poems are addressed to one Amanda, but nothing is known about her, and some critics question her existence as a living person.

37 He was not the only one. I am not fluent in Swedish literature as a whole, but famous opium users in England included T.S. Coleridge, Thomas Quincey, George Crabbe, Percy B. Shelley, John Keats, and finally Lord Byron, and in Wales, the famous writer Iolo Morganwg (the pen name of Edward Williams, 1747-1826).

38 A genetic disorder characterized by short stature, large head, small nose and low-placed ears. The last three features seem to agree with Stagnelius's known portrait. Leonard Neuger (Neuger 1991, p.8) quotes the words of one of the easy virtue ladies who knew Stagnelius, describing him as "extremely ugly; small posture, thin and crooked; deep-set hazel eyes, cherry-colored face." Erik Gustaf Geijer, the founder of the Gothic League, remembered Stagnelius as an "affable though strange, hairy, tippler creature" (ibid.). In brief, a Mr. Hyde to Bellman as Dr. Jekyll. The Swedish sources say that two of the poet's brothers had the same psychic problems, but they do not specify what problems they were. 
Stagnelius's disappointment that his few published poems had not been well received. All in all, his life seems to be foreshadowing the one of Franz Kafka (1883-1924).

So short a life, and so tragically lonely.

Stagnelius published, privately and anonymously, at least three of his works: the epic poem Vladimir the Great ${ }^{39}$ (1817), three parts of Lillies of Sharon ${ }^{40}$ (1821), and a tragedy Bacchantes or Fanaticism (1822). A few years earlier, in 1818, he won the second prize in the poetic competition of the Swedish Academy with the poem titled Song of the Nordic Women, and received the prize himself. This is about all we can say of his poetic career when he was alive.

His poems and dramas published posthumously earned him - rightly! - the fame of one of the greatest masters of the Swedish language, but the views behind the poems do not make a consistent whole. The debut poem Vladimir the Great praises Russia and the Catholic Christianity, both topics not exactly welcome in Sweden. This praise of power, admiration of the stronger one, may reflect the fact that Stagnelius was short and physically weak, so maybe the admiration of the great and mighty was a natural reaction. The Lillies of Sharon include most of his best-known shorter poems. Four dramas were published posthumously:

- Riddartornet (The Knight Tower), a tragedy based on incest motive;

- Glädjeflicjan i Rome (Pleasure Girl of Rome), in which the ghost of the dead criminal calls upon his living lover to come to join him in the realms of the dead;

- Albert och Julia (Albert and Julia), in which the spirit of a woman gives up staying in heaven for joining her lover in hell;

- Torsten fiskare (Torsten the Fisherman), a comedy based on the king-for-a-day motive $e^{41}$.

In the introduction to the Polish translation of Stagnelius's selected poems Leonard Neuger ${ }^{42}$ attempts at reconstructing the poet's views, which according to him are grounded in fosforism ${ }^{43}$. Let us briefly summarize what fosforism was all about.

According to fosforism, there are three worlds or three levels of existence: the $\mathrm{Na}$ ture, the world of ideas, and the world of feelings. There is a constant interchange between the three that is described as correspondences ${ }^{44}$, as the visible world is but a reflection of the invisible one. The fall of man was trusting matter instead of spirit, darkness instead of light, appearances instead of realities. The entire history divides into two parts, before and after the Fall. Neuger calls this view of history "Manicheist"

\footnotetext{
39 Vladimir the Great, born ca. 958, ruler of Kievan Rus since 980 until his death in 1015.

40 Title alluding to Song of Songs II: 1.

41 The brief descriptions of these four plays are based on the Swedish-language Wikipedia biography of Stagnelius (accessed 10.07.2017).

42 Neuger 1991, op. cit., p. 14.

43 A specifically Swedish school of thinking developing the ideas of early German Romanticism (Karl and August Schlegel, Friedrich Schelling, Ludwig Tieck, Novalis). The name comes from the journal Fosforos whose first volume appeared in 1810.

44 This is the key term in Emanuel Swedenborg's (1688-1772) theology.

45 This duality brings to mind Zoroastrianism and the Avesta, one of Mani's (215-275) chief sources of inspiration.
} 
The result is obvious - the entire universe is full of suffering ${ }^{46}$. Man is alone in it, which adds to the suffering, and what is more, man remembers that life and world may be different, but are not. As we see, it is a philosophy as far from joy as possible, and even its name - suggesting the existence of Light ${ }^{47}$ - does not fill one with optimism.

Not having all of Stagnelius's works before me I cannot enter into polemic with Neuger, but his summary of Stagnelius's thinking is well-reflected in the poems he chose to translate into Polish. The translations are masterly - that is the only word that can describe them. They prove that translating Poetry, not only poems, is possible if the translator knows his own language, not only the "other" one.

Stagnelius is sometimes compared to two British poets, Percy B. Shelley (17921822) and William Blake (1757-1827). As English poets are much better known all over the world than the Swedish ones, let us say a few words about these comparisons.

Maybe it is obvious that Stagnelius should be compared to Shelley, as the two poets were almost exact contemporaries - Shelley lived 1792-1822, and Stagnelius, 17931823) - and both took opium. Here, however, the similarities end. The most frequent key words to describe Shelley's views are idealism, nonconformism, nonviolence, social justice for the poor, and vegetarianism. Can we see any similarities between him and Stagnelius? The Swedish poet sang the glory of the absolute ruler, his nonconformism expressed itself chiefly in drinking and carousing, and the noble ideas or social justice and vegetarianism seem to be unknown to him. Of course, we may interpret Stagnelius's stressing the loneliness of man as a kind of social justice dream, but this would require a considerable amount of licentia poetica. Shelley was the Bard of Light, Stagnelius, of Darkness, even though they were contemporaries.

More similarities can be found if we compare Stagnelius with William Blake. Of course, Blake was the Bard of the Free ${ }^{48}$, like Shelley, and Stagnelius's admiration of absolute rulers is as far from Blake as one can imagine. And yet - Blake's world, most obviously the world of the Songs of Innocence, and less obviously so, the world of the Songs of Experience and the Prophetic Books, has one feature that is found in abundance in Stagnelius's poems - Magic, spelt with a capital letter. In this world, or in these worlds, everything is full of magic. Compare Blake's The Sick Rose with Stagnelius's Look at This Flower! ${ }^{49}$; Hear the Voice of the Bard with How Cruelly the Chains of the Mundane Do Bind $M e^{50}$; or finally, the entire Songs of Innocence and of Experience with just one poem by Stagnelius, The Blush ${ }^{51}$. It seems that the Swedish poet said in one poem that for which Blake needed two books.

\footnotetext{
46 This brings to mind Buddhist philosophy, as Buddhism teaches that suffering (not necessarily physical, but also the feeling of want, deprivation of something that I think would make me happy) is the one feature known to all sentient beings.

47 The word phosphorus means "bringing light" in Greek. This again brings to mind the Buddhist key term - enlightenment.

48 Let us remember the trouble Blake got himself into by literally kicking out an intruding soldier from his garden.

49 I am retranslating the Polish title into English, as I do not have Stagnelius's poems in Swedish before me.

50 Cf. the previous footnote.

51 To argue for the validity of comparison with Blake I will now give a brief summary of The Blush.
} 
Or maybe I am wrong, for The Blush can also be seen as the Scandinavian counterpart to Blake's The Mental Traveller, as hauntingly close as can be. I cannot say when The Blush was written, but the probable period is not long, as it has to be between Stagnelius's debut in 1817 and his death six years later. The Mental Traveller is not dated, neither is the Pickering Manuscript from which it comes. Blake scholars date the poem for 1803 or $1805^{52}$. Blake did not etch or illustrate the poem, and it is believed that it was intended to be read aloud from the manuscript, a bit untypical for Blake.

As a musician performing on the Norwegian eight-string Hardanger fiddle I could write a separate paper on Stagnelius's poem The Water Demon ${ }^{53}$ which immediately brings to mind the Fossegrimmen or Waterfall Guardian, The Nix.

It is difficult to compare Stagnelius to any Polish poet, but I think that if we could imagine a triangle whose apexes would be formed by Mikołaj Sęp Szarzyński’s poems (melancholy), Franciszek Karpiński (Laura and Filon, sentimentalism), and Juliusz Słowacki (Król Duch, the philosophical sweep and grandeur), Stagnelius would be in the centre of $\mathrm{it}^{54}$.

As in the case of Tegnér and Bellman, I can only invite the reader to get acquainted with some of Stagnelius's poems on the PoemHunter.com webpage, even though the selection does not give the poet full justice. Let me quote the opening lines of some of the poems available on the web at PoemHunter.com, followed by my own rendering of the first two stanzas of The Blush.

\begin{abstract}
ETERNITY
Up through the ruins of my earthly dreams

I catch the stars of immortality;

What store of joy can lurk in heaven for me?

What other hope feed those celestial gleams?
\end{abstract}

$(\mathrm{PH})$

\footnotetext{
It opens with the image of a beautiful, innocent child, not knowing what suffering is, playing in the fields and enjoying Nature. A beautiful girl appears, looks at the child, whispers his name and kisses him. His blood immediately boils and he discovers the so-far unknown feeling of shame. The nolonger child has a vision of his life and his last dream in the Garden of Eden. He communes with the angels, sees the girl again, they consummate their love, and the feeling of time is born. The no-longer child begs God to turn the dream into reality or to let him dream forever. He is then brought down to the earth and all he remembers is the memory of that first kiss that turned into shadow and sorrow.

52 Cf. William Blake, The Complete Poems, Penguin Classics 1977, p. 960.

53 The Swedish title is Nacken.

54 Mikołaj Sęp Szarzyński lived ca. 1550-1581. He is probably the most eminent Polish metaphysical poet. His Polish poems (he wrote in both Polish and Latin) were first published by his brother in 1601. Franciszek Karpiński, 1741-1825, is the best known Polish sentimentalist, chiefly thanks to the idyll Laura and Filon of 1780. Juliusz Słowacki (1809-1849) is one of the great "Trinity" of the Polish Romantic poets. His philosophic epos Król Duch (King Spirit or The Royal Spirit), whose first part was published in 1847 , was left unfinished. It is, philosophically speaking, the most important achievement of Polish Romanticism.
} 
O CAMP OF FLOWERS

O camp of flowers, with poplars girded round,

Gray guardians of life's soft and purple bud!

O silver spring, beside whose brimming flood

My pensive childhood its Elysium found!

LUNA

Deep slumber hung o'er sea and hill and plain;

With pale pink cheek fresh from her watery caves

Slow rose the moon out of the midnight waves

Like Venus out of ocean born again.

NACKEN - WATER DEMON ${ }^{55}$

The evening is festooned with golden cloud

the fairies dance in the meadow

And the leaf-crowned Nacken

Plays his fiddle in the silvery brook.

THE BLUSH

A carefree child I roamed the grass of yore Not knowing any pains or passions bliss The wind was playing with my hair galore And sunlight filling my whole soul with ease.

All of a sudden, beautiful maiden came With roses in her long, dark, silky hair, Her arm uncovered by the red scarf flame Her bosom breathing naked springtime air $^{56}$.

(PK)

\section{Some Conclusions}

A paper ought to have at least some conclusions. As this one was written to prove that there does exist great poetry in Swedish, I hope that this aim has been achieved.

We can see three different Human Images ${ }^{57}$ before us. Bellman and his Fredman are maybe most appealing in the age where the few rich are again despising and neglecting the rapidly increasing ranks of the poor. If you cannot do anything else, laugh at them, ridicule them, show them they are mere bloated gas bags, hypocrites crossbred with petty fraudsters, or in one immortal name, Tartuffes. Bellman reminds us that the poor

55 The Nix.

56 I will not dare going on - I just hope that these two stanzas will convince the sceptical readers that comparing Blake and Stagnelius is well-founded, and that it is well worth learning Swedish if only for its poetry.

57 To those not (yet!) knowing William Blake - The Human Image is one of the key Songs of Experience. 
are also human beings with their own dignity. Most of them are not poor by choice, but by the injustice of law or the society. Their weapon is laughter, scorn, ridicule - and satire is a weapon well and truly deadly.

Vesti la giubba e la facia infarina

Le gente paga, e rider vole qua...

Ridi, Pagliaccio, sul tuo amore infranto!

Ridi del duol, che t’avvelena il cor! ${ }^{58}$

The life and works of Tegnér show us another image. A child thirsting for knowledge can rise from rags to academia, but the sensibility, the feeling of the injustice of the world, may defeat even the strongest spirit. Instead of capitalizing on his fame, the author of Frithjof Saga succumbed to melancholy and depression - he who was a bishop, whose job, well, a part of it, was telling the poor that God loves them and takes care of them even though they - most likely - do not see any signs of it. Again, there is a lesson in it fit for our times. It is simple - let us not be defeated by the prevailing feeling of injustice, let us not succumb to gloom. No pasarán! ${ }^{59}$

And finally, the strange case of Dr. Stagnelius and Mr. Stagnelius ${ }^{60}$, the poet who could turn a flower into a world and a world of flowers into Mordor ${ }^{61}$. His life was brief, bleak and tragic. Can we learn anything from him? The answer is simple - we must remember that Light comes to Beauty, and we can find it wherever we turn, if only we want to look for it. As a common saying has it, there is a light at the end of the tunnel. Let us focus on it, no matter how many miles of darkness separate us from it. It may be a long way, too long to us - but Light and Beauty are there at the end of it. Really. Paraphrasing Stagnelius's sublime poetry in prose, even the vast realm of damp tombs fires up with the gold of the dawn ${ }^{62}$. Would he write the same poems were he tall, handsome and athletic? Is it enough to remember that to everything there is a reason, and a time for every purpose under heaven ${ }^{63}$ ?

Both in Norway and Denmark I have heard - many times - that the Nordic language for poetry is Swedish ${ }^{64}$. I was not convinced then, but I think I can understand it now.

\section{Acknowledgement}

I wish to thank Leonard Neuger for his breathtaking Polish translations of Bellman's and Stagnelius's poems. Please, Mr. Neuger, if this paper reaches you, give us more Stagnelius in Pol-

58 I invite the readers to listen to Leoncavallo's Pagliacci for the entire aria Vesti la giubba e la facia infarina/Put on your costume, powder your face.

59 I hope the name of Dolores Ibárruri Gomez is not yet totally forgotten.

60 I cannot but think of him as Dr. Jekyll and Mr. Hyde in one, not two separate bodies.

61 I hope that Tolkien's admirers will forgive me this comparison. I add that I know The Lord of the Rings almost by heart.

62 This is the conclusion of Stagnelius's poem Wayfaring Birds (cf. footnote 38).

63 Ecclesiastes III: 1.

64 I must admit, though, that most of my literary friends voicing this opinion did not know Faroese and Icelandic, and very few had any knowledge of Nynorsk (New Norwegian) poetry. I think that the experience of listening to - I stress, listening to, not just looking at the printed pages - Janus Djurhuus's (1881-1948) translation of the Iliad (Illionskvæđi, published posthumously in Tórshavn in 1967) would convince many that Faroese has just as strong a claim to the distinction. 
ish and think of completing the trilogy with the new Polish translation of Tegnér's Frithjof Saga! You are a Master of Polish, not only Swedish. In the times when our language degenerates into Polglish you prove that pure Polish is still alive, unbelievably rich and beautiful. Who could do justice to Tegnér's and Stagnelius's masterpieces better than you?

\section{Plates}

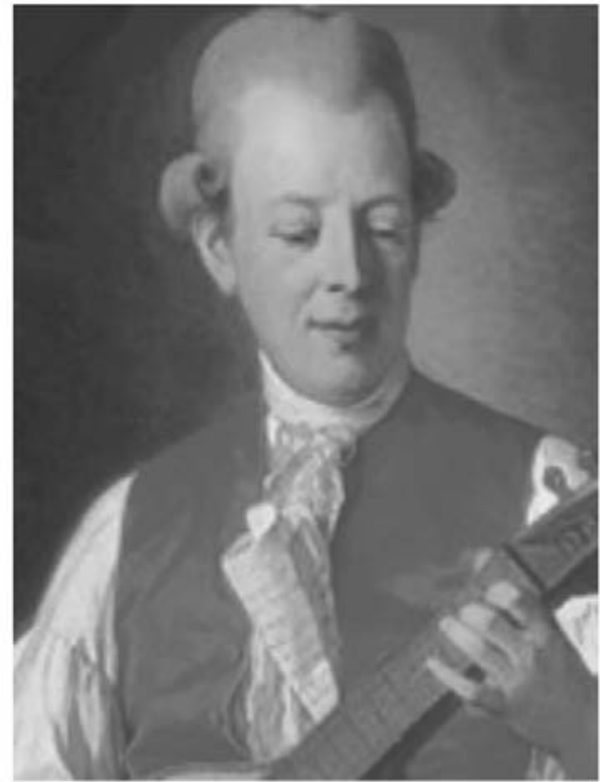

Plate One - Carl Michael Bellman playing his cittern. Portrait by Per Krafft the Elder, 1779 http://historiesajten.se/visainfo.asp?id=58

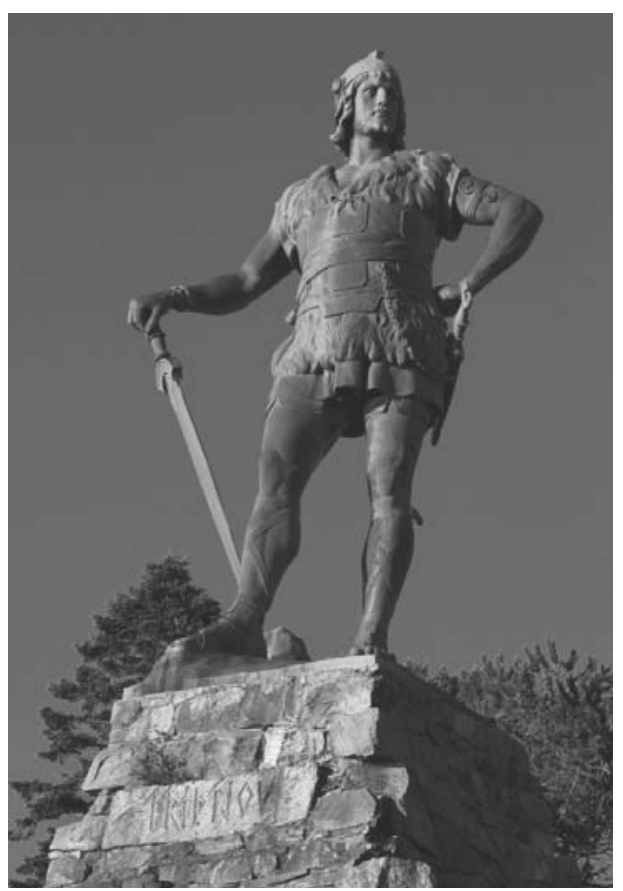

Plate Three - Frithjof's monument in VAngsnes, Norway (see fn. 29)

https://de.wikipedia.org/wiki/Frithjofssage

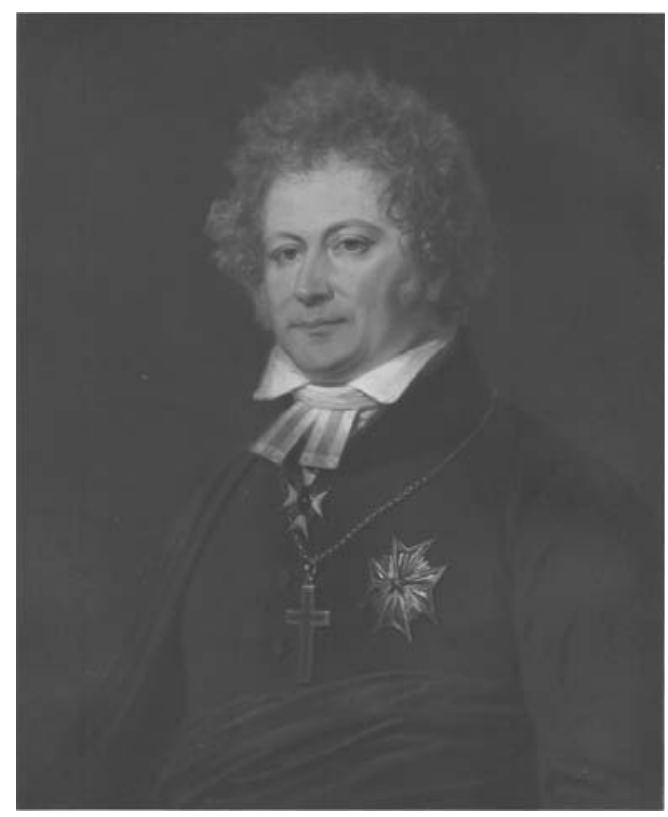

Plate Two - Esaias Tegnér, portrait from Svenska Familj Journalen of 1870

https://sv.wikipedia.org/wiki/Esaias_Tegn\%C3\%A9r

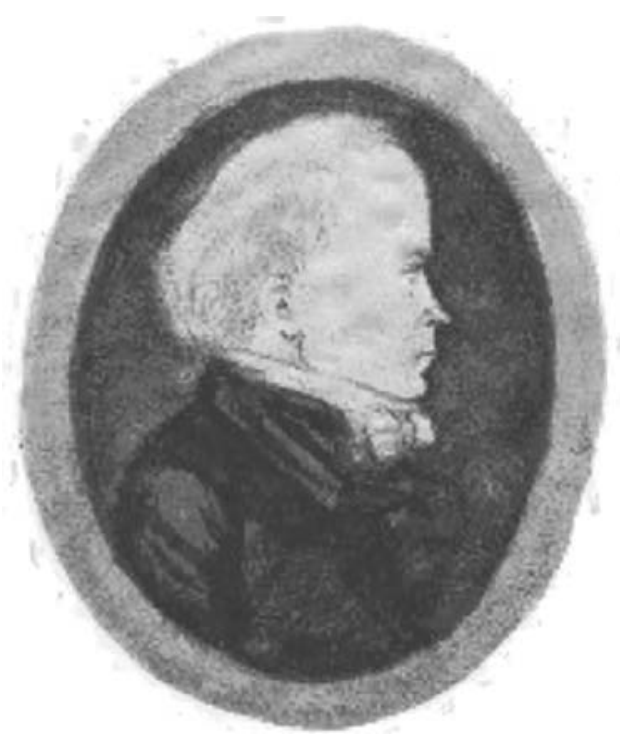

Plate Four - Erik Johan Stagnelius. The Swedishlanguage Wikipedia informs us that this portrait was painted after a silhouette taken from life, apparently the only existing picture of the poet https://upload.wikimedia.org/wikipedia/commons/d/dd/Erik_Johan_Stagnelius\%2C_color.jpg 


\section{Bibliography}

\section{Histories of Scandinavia.}

Derry T.K. A History of Modern Norway 1814-1972. Oxford: Clarendon Press, 1973.

Derry T.K. A History of Scandinavia: Norway, Sweden, Denmark, Finland, Iceland. University of Minnesota Press, 2000.

Höjer T.T. Carl XIV Johan. 3 vols. Stockholm: P.A. Norsted \& Sönners Forlag, 1939 (vol. 1), 1943 (vol. 2), 1960 (vol. 3).

Kent N. A Concise History of Sweden. Cambridge: Cambridge University Press, 2011.

\section{Carl Michael Bellman.}

\subsection{Printed books}

Bellman, Carl Michael - see Neuger 1991.

Britten A.P. The Life and Songs of Carl Michael Bellman: Genius of the Swedish Rococo. Malmö and New York: American-Scandinavian Foundation, 1967.

Britten A.P. Carl Michael Bellman: Sweden's Shakespeare of the Guitar Song. Stockholm: Proprius, 1998.

Húlden L. Carl Michael Bellman. Stockholm: Natur och kultur, 1991 (in Swedish).

Neuger L. Fredmanowe Posłania i Pieśni. Selected and translated by Leonard Neuger. Warszawa: Polskie Wydawnictwo Muzyczne, 1991 (in Polish).

1.2. Internet sources, all accessed 1.07.2017.

Carl Michael Bellman, biografi. Wikipedia, in Swedish.

Carl Michael Bellman, biography. Wikipedia, in English.

Fredmans Epistlar (in Swedish).

Fredmans Epistlar (in English).

Fredmans Sånger (in Swedish).

Fredmans Sånger (in English).

PoemHunter.com - Poems by Carl Michael Bellman.

1.3. Discography.

Fredman's Epistles and Songs. Performed by Martin Bagge and Helena Ek. CD record. B.E.L.L. Musique 2002.

Songs of Carl Michael Bellman. Performed by Martin Best. CD record. Nimbus Records 1997.

\section{Esaias Tegnér.}

\subsection{Printed books.}

Böök F. Esaias Tegnér. Stockholm: Bonniers, 1946

Gale R.L. A Henry Wadsworth Longfellow Companion. Westport (Connecticut) and London: Greenwood Press, 2003.

\subsection{Frithjof's Saga.}

Tegnér E. - Frithiof's Saga. Translated into English verse by Henry Wadsworth Longfellow, Luciuus Sherman, Thomas and Martha Holcomb, and William Blackley, with the introductory notes to the cantos by Longfellow and the general introduction by Bayard Taylor. Stockholm: The Limited Editions Club, P.A. Norstedt \& Söner, 1953. 
Tegnér J. Frithiofowa Saga. Przełożył, wstępem i objaśnieniami opatrzył Stanisław Wałęga. Biblioteka Narodowa Seria II, Nr 108. Wrocław-Kraków: Zakład Narodowy im. Ossolińskich - Wydawnictwo, 1957 (in Polish).

2.3. Internet sources, all accessed 1.07.2017.

Esaias Tegnér, biografi (In Swedish).

Esaias Tegnér, biography (in English).

Fridfjófs saga hins froekna (in Swedish and English, both under the same title).

Frithiofs Saga (in Swedish).

PoemHunter.com - Poems by Esaias Tegnér.

2.4. Epic Poetry in Norway.

Klafkowski P. Hans Henrik Holm, the Last Homer of Europe. [In:] "Czas Kultury”. Nr 5-6, Poznań 1995, pp. 11-23. (in Polish).

Klafkowski, P. Where the Folk and the Individual Meet. Nynorsk Poetry and its Connections with Folk Literature. [In:] "Literatura Ludowa: dwumiesięcznik naukowo-literacki". Nr 6, listopad-grudzień 2016, Wrocław, pp. 33-43.

Discography.

Frithiofs Saga, ur Tegnérs Frithiofs Saga till folkliga melodier. Performed by Katarina Jerkersdotter, Hans Grönlund, Agneta Stolpe, Matts Arnberg, Anders Eklundh, Lars Höpkers, Sverre Jensen and Tommy Ridde. Cinober Records CINLP 3, an analogue LP, 1986.

\section{Erik Johan Stagnelius.}

3.1. Printed books.

Neuger L. Erik Johan Stagnelius. Elegie. Wybrał, przełożył i wstępem opatrzył Leonard Neuger. Kraków: Oficyna Literacka, 1991.

3.2. Internet sources, all accessed 1.07.2017.

Erik Johan Stagnelius, biografi. Wikipedia (In Swedish).

Erik Johan Stagnelius, biography. Wikipedia (in English).

PoemHunter.com - Poems by Erik Johan Stagnelius.

3.3. Comparisons to William Blake.

Blake W. The Complete Poems. Edited by Alicia Ostriker. London: Penguin Classics, 1977.

Blake W. The Complete Poetry and Prose of William Blake. Edited by David V. Erdman, Commentary by Harold Bloom. New York: Anchor Books, a Division of Random House, Inc., 1988.

Blake and Swedenborg. Opposition is True friendship. The Sources of William Blake's Arts in the Writings of Emanuel Swedenborg. An Anthology. Compiled and Edited by Bellin H.F. and D. Ruhl, in conjunction with G.F. Dole, T. Kieffer and N. Crompton, with an Introduction by George F. Dole. New York: Swedenborg Foundation Inc., 1985.

Damon S.F. A Blake Dictionary. Hanover and London: University Press of New England, 1988.

Rose J.S., S. Shotwell, M.L. Bertucci (Eds.). Scribe of Heaven. Swedenborg's Life, Work, and Impact. West Chester (Pennsylvania): Swedenborg Foundation, 2005.

Swedenborg E. The Universal Human and Soul-Body Interaction. New York-Mahwah: Paulist Press, 1984.

\section{English dictionaries used.}

[Maybe this section needs an introductory word. Reading and translating poetry frequently demands a rather special vocabulary that not many dictionaries include. I have a group of dictionaries that are my very special friends, for they never fail me in finding the word I need, teaching me a lot along the way. I wish to thank them all here.] 
Chambers $20^{\text {th }}$ Century Thesaurus, a comprehensive word-finding dictionary. Edited by M.A. Seaton, G.W. Davidson, C.M. Schwarz, J. Simpson. Edinburgh: Chambers, 1986.

Fernald J.C. Synonyms, Antonyms \& Prepositions. New York: A Funk \& Wagnalls Book Published by Thomas Y. Crowell, 1947.

Lewis N. The Comprehensive Word Guide. With an Introduction by Clarence Barnhart. New York: Doubleday \& Company, Inc. Garden City, 1958.

March F.A. March's Thesaurus and Dictionary. With an Introduction by C.L. Barnhart, issued under the Editorial Supervision of N. Cousins, with a New Supplement by R. A. Goodwin. New York: Doubleday \& Company, Inc. Garden City, 1958

March F.A. March's Thesaurus and Dictionary of the English Language. Under the Editorial Supervision of Norman Cousins, with a New Supplement by R. A. Goodwin and S. Flexner. New York: Abbeville Press Publishers, 1980.

[This, to me, is the best English thesaurus ever published, and I invite all the sceptics to consult it and see for themselves.]

The Random House Dictionary of the English Language. The Unabridged Edition. J. Stein (Editor in Chief), L. Urdang (Managing Editor). New York: Random House, 1967.

The Random House Dictionary of the English Language. College Edition. L. Urdang (Editor in Chief), S.B. Flexner (Managing Editor). New York: Random House, 1968.

Reader's Digest Word Power Dictionary. Edited by A. Wevell and W. Powell. Cape Town: The Reader's Digest Association South Africa (Pty) Limited, 1996, reprinted 2000.

Roget P.M. Roget's Thesaurus, Facsimile of the First Edition of 1852 with an Introduction by Laurence Urdang. London: Bloomsbury, 1987.

Stillman F. The Poet's Manual and Rhyming Dictionary. London: Thames and Hudson, 1966. 